\title{
VEGF- $A_{165}$ potently induces human blood-nerve barrier endothelial cell proliferation, angiogenesis and wound healing in vitro
}

Chetan Lakshmana Reddy, M.S. ${ }^{a}$, Nejla Yosef, M.S. ${ }^{a}, 1$, and Eroboghene E. Ubogu, M.D. ${ }^{a}$ aNeuromuscular Immunopathology Research Laboratory, Department of Neurology, Baylor College of Medicine, Houston, Texas, United States of America

\begin{abstract}
Several mitogens such as vascular endothelial growth factor (VEGF) have been implicated in mammalian vascular proliferation and repair. However, the molecular mediators of human bloodnerve barrier (BNB) development and specialization are unknown. Primary human endoneurial endothelial cells (pHEndECs) were expanded in vitro and specific mitogen receptors detected by western blot. pHEndECs were cultured with basal medium containing different mitogen concentrations with or without heparin. Non-radioactive cell proliferation, Matrigel ${ }^{\mathrm{TM}_{\text {-induced }}}$ angiogenesis and sterile micropipette injury wound healing assays were performed. Proliferation rates, number and total length of induced microvessels and rate of endothelial cell monolayer wound healing were determined and compared to basal conditions. VEGF- $\mathrm{A}_{165}$ in the presence of heparin, was the most potent inducer of pHEndEC proliferation, angiogenesis and wound healing in vitro. $1.31 \mathrm{nM}$ VEGF- $\mathrm{A}_{165}$ induced $~ 110 \%$ increase in cell proliferation relative to basal conditions ( $\sim 51 \%$ without heparin). 2.62 pM VEGF- $\mathrm{A}_{165}$ induced a 3 -fold increase in mean number of microvessels and 3.9-fold increase in total capillary length/field relative to basal conditions. In addition, $0.26 \mathrm{nM}$ VEGF- $\mathrm{A}_{165}$ induced $~ 1.3$-fold increased average rate of endothelial wound healing 4-18 hours after endothelial monolayer injury, mediated by increased cell migration. VEGF-A 165 was the only mitogen capable of complete wound closure, occurring within 30 hours following injury via increased cell proliferation. This study demonstrates that VEGF- $\mathrm{A}_{165}$, in the presence of heparin, is a potent inducer of pHEndEC proliferation, angiogenesis and wound healing in vitro. VEGF- $\mathrm{A}_{165}$ may be an important mitogen necessary for human BNB development and recovery in response to peripheral nerve injury.
\end{abstract}

\section{Keywords}

Blood-nerve barrier; endoneurial endothelial cell; growth factor receptors; mitogen; vascular endothelial growth factor

\footnotetext{
Corresponding author/address: Eroboghene E. Ubogu, M.D., Department of Neurology, Baylor College of Medicine, One Baylor Plaza, Mailstop NB302, Houston, TX 77030-3411, United States of America., Telephone Number: +1-713-798-4654, Facsimile Number: +1-713-798-3676, ubogu@bcm.edu.

${ }^{1}$ Current address, Department of Molecular Physiology and Biophysics, Baylor College of Medicine, Houston, Texas, United States of America.
}

CONFLICT OF INTEREST

There are no financial conflicts of interest to disclose. 


\section{INTRODUCTION}

The restricted internal microenvironment of the peripheral nerve endoneurium (which contains myelinated and unmyelinated axons responsible for action potential transmission to and from the central nervous system) is regulated by specialized tight junction-forming microvascular endoneurial endothelial cells that restrict the passive diffusion of solutes, macromolecules, leukocytes and microbes from the blood circulation, and specialized perineurial cells that form concentric layers around the endoneurium, restricting diffusion of substances from the freely permeable epineurium into the endoneurium (Olsson 1990; Reina et al. 2000; Reina et al. 2003). Due to the direct interaction of endoneurial endothelial cells with circulating blood, these cells can be considered to form the blood-nerve barrier (BNB). The BNB is second only to the blood-brain barrier (BBB) in terms of restrictive capabilities in mammals (Malmgren and Olsson 1980; Poduslo et al. 1994; Allt and Lawrenson 2000).

Very little is known about human BNB development, maturation and response to injury. Functional and biochemical changes may occur at the human BNB during normal development and in certain neuropathies (Pummi et al. 2004; Poduslo et al. 1988; Kanda et al. 2004). BNB studies in animals provide insights that may be relevant to humans (Poduslo et al. 1994; Allt and Lawrenson 2000; Orte et al. 1999; Hirakawa et al. 2003; Olsson 1971; Smith et al. 2001). However, there are phenotypic and functional differences between vascular endothelial cells from different species, endothelial cells from different tissues within the same species and macrovascular and microvascular endothelial cells within the same tissue (Aird 2007a, b; Bell and Weddell 1984a, b; Allt and Lawrenson 2000; Orte et al. 1999; Sano et al. 2007; Reina et al. 2000; Man et al. 2008; Murphy et al. 1998; Latker et al. 1987). Endothelial cell differentiation is dependent on its specialized tissue microenvironment and function. These observations are evolutionally conserved down to invertebrates such as the hagfish (Yano et al. 2007). In order to fully understand the possible determinants and signaling pathways responsible for human BNB development and response to injury in vivo, in vitro studies using human BNB-forming endothelial cells can provide important insights.

Studies on the BBB and other vascular barriers in humans and other species have resulted in extensive knowledge on the mediators and mechanisms of endothelial cell proliferation and specialization. Extensive studies evaluating mammalian central nervous system vascular responses to external insult provide clues that may be relevant to the human BNB (KrizanacBengez et al. 2004; Marchi et al. 2010; Arai et al. 2009; Guo and Lo 2009; Al Ahmad et al. 2009; Stonestreet et al. 2000; Zheng and Yenari 2004; Engelhardt and Ransohoff 2005; Man et al. 2007). Molecules such as vascular endothelial growth factor (VEGF) (Shibuya 2008, 2009; Galvan et al. 2006; Sun et al. 2003; Wang et al. 2007; Tang et al. 2009), basic fibroblast growth factor (bFGF) (Sobue et al. 1999; Bendfeldt et al. 2007), glial cell-derived neurotrophic factor (GDNF) (Utsumi et al. 2000), transforming growth factor beta-1 (TGF$\beta 1$ ) (Garcia et al. 2004), and steroids, e.g. dexamethasone and hydrocortisone (Sadowska et al. 2010; Stonestreet et al. 2000; Förster et al. 2005; Weidenfeller et al. 2005) have been implicated in these biological processes, through defined or emerging signaling pathways (Schlessinger 2004; Takahashi 2001; Wakefield and Roberts 2002; Shabb 2001).

We recently demonstrated an important role for GDNF in restoring the restrictive barrier characteristics of the human BNB in vitro following serum withdrawal (mimicking diffuse endothelial cell injury) via RET-tyrosine kinase dependent signaling pathways (Yosef and Ubogu 2012). Although GDNF was the most efficacious mitogen tested, TGF- $\beta 1$, bFGF, hydrocortisone and cyclic adenosine monophosphate/ protein kinase A signaling pathways provided some redundancy in vitro. VEGF has been shown to alter tight junction protein expression by peripheral nerve microvascular cells (PnMECs) following exposure to 
advanced glycation end-products (mimicking diabetic conditions) in vitro (Shimizu et al. 2011b). Similarly, growth factors expressed by immortalized human pericyte cell lines, bFGF, GDNF and hydrocortisone have been shown to enhance claudin-5 expression by primary or immortalized PnMECs determined by western blot within 48 hours of culture, suggesting roles in promoting tight junction formation in vitro (Kashiwamura et al. 2011; Shimizu et al. 2011a; Shimizu et al. 2012).

Despite these early advances in understanding human BNB biology supported by the recent isolation of primary human endoneurial endothelial cells (pHEndECs) and PnMECs, and their stable immortalization which has resulted in established cell lines (Yosef and Ubogu 2013; Abe et al. 2012), the full repertoire of mitogens, co-factors and growth factor receptors required for $\mathrm{pHEndEC}$ proliferation, angiogenesis and response to direct trauma are currently unknown. This study demonstrates an important role for physiological concentrations of VEGF in these biological processes at the human BNB in vitro.

\section{MATERIALS AND METHODS}

\section{Antibody and Reagents}

Mouse monoclonal anti-human VEGFR2 IgG1 (clone A3) and anti-human glyceraldehyde-3-phosphate dehydrogenase (GAPDH) IgG1 (clone 0411); polyclonal rabbit anti-human FGFR1 IgG (C-15), anti-human GFRa1 IgG (H-70), anti-human glucocorticoid receptor (GR) IgG (H-300), anti-human TGFßRI IgG (V-22) and anti-human TGFßRII IgG (L-21) were purchased from Santa Cruz Biotechnology (Santa Cruz, California, USA). Horseradish peroxidase-conjugated AffiniPure polyclonal goat anti-mouse and goat antirabbit IgG $(\mathrm{H}+\mathrm{L})$ antibodies were purchased from Jackson ImmuoResearch Laboratories (West Grove, Pennsylvania, USA). Recombinant human VEGF-A polypeptide 165 amino acid variant (VEGF-A 165 ), GDNF, bFGF and TGF- $\beta 1$ were purchased from PeproTech (Rocky Hill, New Jersey, USA). Hydrocortisone and heparin sodium salt (derived from porcine intestinal mucosa) were purchased from Sigma-Aldrich (St. Louis, Missouri, USA). The nonradioactive tetrazolium salt WST-1 (4-[3-(4-Iodophenyl)-2-(4-nitrophenyl)-2H-5tetrazolio]-1, 3-benzene disulfonate) was purchased from Roche Applied Sciences (Indianapolis, Indiana, USA). Matrigel ${ }^{\mathrm{TM}}$ Basement Membrane Matrix, derived from Engelbreth-Holm-Swarm Mouse Tumor, was purchased from BD Biosciences (Bedford, Massachusetts, USA).

\section{Primary human endoneurial endothelial cell (pHEndEC) isolation and culture}

The work described was carried out in accordance with The Code of Ethics of the World Medical Association (Declaration of Helsinki), conforming to the Uniform Requirements for manuscripts submitted to Biomedical journals. An exemption from the Baylor College of Medicine Institutional Review Board (protocol number H-22347) was obtained to harvest endothelial cells from recently decedent individuals undergoing routine medical autopsy. pHEndECs were isolated, purified and characterized as previously described (Yosef et al. 2010) and expanded by culture on rat tail collagen (RTC)-coated Corning CellBIND® tissue culture plates in regular growth medium. The cells were cultured at $37^{\circ} \mathrm{C}$ in a humidified atmosphere with $95 \%$ air/ $5 \% \mathrm{CO}_{2}$ in an incubator, as previously described (Yosef et al. 2010), and passaged at $80-90 \%$ confluence. Cultures from passages $6-8$ were used for subsequent studies.

\section{Western blot analysis}

Total cellular (cytoplasmic and membrane) proteins were extracted from proliferating pHEndEC, simian virus 40 large-T antigen (SV40-LTA) immortalized human endoneurial endothelial cell (THEndEC, passage 20) and SV40-LTA immortalized human brain 
microvascular endothelial cell (THBMEC: kind gift from Dr. Monique Stins, passage 20) cultures grown to near-confluence in $75 \mathrm{~cm}^{2}$ Corning CellBIND ${ }^{\circledR}$ tissue culture flasks, as previously published (Yosef and Ubogu 2012, 2013). Protein extracts were quantified using the Bradford Coomassie assay and stored at $-80^{\circ} \mathrm{C}$. Equal amounts of protein $(4 \mu \mathrm{g})$ were denatured, reduced and separated by sodium dodecyl sulfate-polyacrylamide gel electrophoresis (SDS-PAGE; 10\% slab gel) using the Bio-Rad MiniProtean III Apparatus (Hercules, California, USA), then electrotransfered to polyvinylidene fluoride membranes in transfer buffer using the Bio-Rad Trans-Blot Apparatus, according to manufacturer instructions.

Membranes were blocked with 5\% non-fat milk or 5\% goat serum in Tris buffered saline + $0.05 \%$ Tween-20 (TBS-T) for 1 hour at RT, followed by incubation with primary antibodies diluted in TBS-T containing $1 \%$ non-fat milk or $1-5 \%$ goat serum overnight at $4{ }^{\circ} \mathrm{C}$ (final concentration $0.4 \mu \mathrm{g} / \mathrm{mL}$ for GFRa 1 , TGF $\beta$ RI, TGF $\beta$ RII and FGFR $1 ; 1 \mu \mathrm{g} / \mathrm{mL}$ for GAPDH, VEGFR2 and GR). Following several washes, membranes were incubated with horseradish peroxidase-conjugated secondary antibodies diluted in TBS-T/ $1 \%$ non-fat milk or TBS-T/ 1-5\% goat serum (1:10,000 dilution) for 1 hour at RT, washed as above, treated with Pierce Enhanced Chemiluminescence western blotting substrate plus detection reagents (Thermo Fisher Scientific, Rockford, Illinois, USA) and visualized by generating autoradiographs following film exposure from 1 minute to 1 hour using an SRX-101A film processor (Konica Minolta, Tokyo, Japan). Digital autoradiograph images were taken using an AlphaImager HP image documentation system (ProteinSimple, Santa Clara, California, USA) attached to a Sony ICX267AL 1.39 Megapixel CCD camera, as previously described. Molecular weight markers confirmed protein size.

\section{pHEndEC proliferation assay}

Freshly passaged pHEndECs were seeded at 5,000 cells per well into flat-bottom 96-well CellBIND® microplates in basal culture medium [RPMI-1640 medium (Invitrogen, Carlsbad, California, USA) containing 10\% NuSerum (BD Biosciences; Bedford, Massachusetts, USA), 10\% fetal bovine serum (PAA Laboratories, New Bedford, Massachusetts, USA), 1X penicillin-streptomycin (Mediatech Inc., Herndon, Virginia, USA), $1 \mathrm{X}$ vitamin solution, $1 \mathrm{X}$ non-essential amino acid solution, $2 \mathrm{mM} \mathrm{L}$-glutamine, $1 \mathrm{nM}$ sodium pyruvate, $10 \mathrm{mM}$ HEPES buffer (all from Invitrogen)], with or without $25 \mathrm{U} / \mathrm{mL}$ heparin. Basal culture medium consists of regular growth medium without added growth supplements (Yosef et al. 2010). The cells were treated with VEGF-A $165(0.1-100 \mathrm{ng} / \mathrm{mL}$ ), bFGF (0.1-500 ng/mL), TGF- $\beta 1(0.1-500 \mathrm{ng} / \mathrm{mL})$, GDNF $(0.1-100 \mathrm{ng} / \mathrm{mL})$ and hydrocortisone (100-5000 nM), to a total volume of $100 \mu \mathrm{L}$ per well, in triplicate. Proliferation relative to basal conditions without added growth factors was quantified by absorbance after 48 hours (during pHEndEC linear growth phase) using the sensitive nonradioactive tetrazolium salt, WST-1, detected with a FLUOstar Optima microplate reader (BMG Labtech, Durham, North Carolina, USA) 4 hours after adding $10 \mu \mathrm{L}$ of WST-1 per well, as previously published (Yosef et al. 2010). Wells containing basal culture medium alone were used for background determination. The optical density (O.D.) is linearly proportional to the number of metabolically active cells for the range used. The percentage increase in proliferation over basal growth for each concentration of mitogen tested was calculated as follows: [(O.D. mitogen - O.D. basal $) \times 100 \%] \div$ O.D. basal.

\section{pHEndEC angiogenesis assay}

pHEndEC angiogenesis under the influence of exogenous growth factors was studied using the 4-hour Matrigel ${ }^{\mathrm{TM}}$ assay, as previously described (Yosef et al. 2010). Freshly passaged pHEndECs were seeded at 12,500 cells $/ \mathrm{cm}^{2}$ in basal culture medium containing VEGF $\mathrm{A}_{165}$ (0.1-100 ng/mL), bFGF (0.1- $500 \mathrm{ng} / \mathrm{mL})$, hydrocortisone $(10-5000 \mathrm{nM}), \operatorname{GDNF}(1 \mathrm{ng} / \mathrm{mL})$ 
and TGF- $\beta 1(0.1 \mathrm{ng} / \mathrm{mL})$ onto 12-well Corning CellBIND® tissue culture plates coated with $50 \mu \mathrm{L} / \mathrm{cm}^{2}$ of Matrigel ${ }^{\mathrm{TM}}$ in RPMI-1640 medium with and without $25 \mathrm{U} / \mathrm{mL}$ heparin. Plates were maintained at $37^{\circ} \mathrm{C}$ in a humidified atmosphere with $95 \%$ air/ $5 \% \mathrm{CO}_{2}$ in an incubator for 4 hours. The mean number and total length of microvessels formed for each concentration of mitogen tested was determined by taking digital phase contrast photomicrographs of each well using an Axiocam MRc 5 digital camera attached to an Axiovert 40 Inverted Microscope (Carl Zeiss Inc. Thornwood, New York, USA) precalibrated with an S8 micrometer scale (Electron Microscopy Sciences, Hatfield, Pennsylvania, USA). These parameters were quantified in triplicate using the Zeiss AxioVision software, and compared to angiogenesis in basal medium.

\section{pHEndEC wound healing assay}

pHEndECs were grown to $>90 \%$ confluence on RTC-coated 12-well CellBIND® tissue culture plates in regular growth medium. A sterile micropipette injury (one vertical and three horizontal lines) was performed in each well using an autoclaved plastic $1000 \mu \mathrm{L}$ micropipette tip (Lee and Kay 2006). Cellular debris was washed away twice by gentle aspiration after adding $500 \mu \mathrm{L}$ of basal medium per well. The endothelial cell monolayers were treated with VEGF-A 165 (1-100 ng/mL), bFGF (1-500 ng/mL), hydrocortisone (100$1000 \mathrm{nM}), 1 \mathrm{ng} / \mathrm{mL}$ GDNF or $0.1 \mathrm{ng} / \mathrm{mL}$ TGF- $\beta 1$ in basal medium with or without $25 \mathrm{U} / \mathrm{mL}$ heparin, to a total volume of $500 \mu \mathrm{L}$ per well. The rate of wound recovery over 30 hours was quantified using computer-assisted measurements of sequential phase contrast digital photomicrographs of the same 10 non-overlapping regions per well. Images were taken hourly and analyzed using the Axiocam MRc5 and Zeiss Axiovision software. The average rate of pHEndEC monolayer wound recovery (in $\mu \mathrm{m} / \mathrm{hr}$ ) was compared to recovery without added growth factors, heparin or both.

\section{Statistical Analyses}

Statistical analyses (unpaired one or two-tailed Student's t-test or analysis of variance) were performed using JMP® version 8 software (SAS Institute), with statistical significance set at $\mathrm{p}<0.05$. Data sets were determined to be normally distributed based on tests for skewness and kurtosis. Data in the text represent mean values. Variations of the mean are expressed as standard errors of mean, further demonstrated by error bars in representative graphs.

\section{RESULTS}

\section{Determination of pHEndEC growth factor receptor expression}

Using THBMECs as a positive control, we demonstrated expression of VEGFR2, FGFR1, TGF $\beta R I$ and TGF $\beta$ RII, GFRa 1 and GR, the receptors for VEGF, bFGF, TGF- $\beta 1$, GDNF and hydrocortisone respectively, on proliferating pHEndECs (Figure 1). We had previously demonstrated GFRa1 expression on pHEndECs by western blot and immunocytochemistry, with increased receptor expression following diffuse endothelial cell injury mediated by serum withdrawal (Yosef and Ubogu 2012). GR expression had been previously demonstrated on immortalized PnMECs (Kashiwamura et al. 2011). Interestingly, VEGFR2 was not detected on contact-inhibited pHEndEC cultures by western blot (data not shown). These receptors were also expressed by THEndECs, implying retention of these growth factor receptors with stable transfection and immortalization, as shown on Figure 1. These data demonstrate that pHEndECs are capable of directly responding to the above mitogens under different experimental conditions in vitro, providing rationale to further determine their roles in BNB endothelial cell proliferation, angiogenesis and wound healing. 


\section{VEGF potently induces pHEndEC proliferation in vitro, in the presence of heparin}

VEGF was the most potent inducer of pHEndEC proliferation in vitro 48 hours after seeding with a mean maximum increase in proliferation relative to basal growth of $110 \pm 2.4 \%$ at a concentration of $50 \mathrm{ng} / \mathrm{mL}(1.31 \mathrm{nM})$, in the presence of heparin. Proliferation rose steeply between $1 \mathrm{ng} / \mathrm{mL}(23.2 \pm 1.9 \%)$ and $10 \mathrm{ng} / \mathrm{mL}(108.8 \pm 2.7 \%)$ and dropped between 50 and $100 \mathrm{ng} / \mathrm{mL}$ (Figure 2). Hydrocortisone (mean maximum increase in proliferation of $71.5 \pm$ $3.0 \%$ at a concentration of $2500 \mathrm{nM})$ and bFGF $(66.0 \pm 2.3 \%$ at $100 \mathrm{ng} / \mathrm{mL}[5.81 \mathrm{nM}])$ demonstrated an equivalent magnitude of effect on $\mathrm{pHEndEC}$ proliferation, with bFGF being similarly potent at a lower molar concentration (Figure 2). Hydrocortisone-induced proliferation showed very little change between 100-2500 nM, while bFGF-induced proliferation was relatively stable with some variation between $1-100 \mathrm{ng} / \mathrm{mL}$, as shown on Figure 2. GDNF had a minor effect on proliferation, with a mean maximum increase in proliferation of $15.8 \pm 2.1 \%$ at a concentration of $1 \mathrm{ng} / \mathrm{mL}(0.03 \mathrm{nM})$ while TGF- $\beta 1$ inhibited pHEndEC proliferation, with a maximum reduction in proliferation compared to basal growth of $28.0 \pm 4.4 \%$ at a concentration of $1 \mathrm{ng} / \mathrm{mL}(0.04 \mathrm{nM})$ that remained unchanged up to a concentration of $500 \mathrm{ng} / \mathrm{mL}$ (Figure 2).

Heparin $(25 \mathrm{U} / \mathrm{mL}$ ) had a positive effect on $\mathrm{pHEndEC}$ proliferation induced by VEGF, bFGF and hydrocortisone (Figure $3 \mathrm{~A}$ ), with a mean percentage reduction in proliferation of $53.6 \%, 48.4 \%$ and $28.1 \%$ observed without heparin at maximum growth-inducing concentrations respectively. GDNF inhibited pHEndEC proliferation in the absence of heparin, with a mean $150 \%$ reduction in proliferation observed at $1 \mathrm{ng} / \mathrm{mL}$ (Figure $3 \mathrm{~A}$ ). TGF- $\beta 1$ more effectively inhibited pHEndEC proliferation in the absence of heparin, with inhibition of $28.2 \pm 1.1 \%$ observed at $0.1 \mathrm{ng} / \mathrm{mL}(0.004 \mathrm{nM}$, Figure $3 \mathrm{~A})$ that remained relatively unchanged between $0.1 \mathrm{ng} / \mathrm{mL}$ and $100 \mathrm{ng} / \mathrm{mL}$, with a gradual reduction in proliferation at higher concentrations that was maximum $(51.7 \pm 1.3 \%)$ at a concentration of $500 \mathrm{ng} / \mathrm{mL}(20 \mathrm{nM})$, as shown in Figure 3B. The reduction in proliferation seen at $500 \mathrm{ng} /$ $\mathrm{mL}$ was satistically significant relative to the reduction observed between $0.1 \mathrm{ng} / \mathrm{mL}$ and $100 \mathrm{ng} / \mathrm{mL}$ (p-values $0.00008,0.037,0.004$ and 0.0003 respectively).

These data suggest that VEGF is a potent inducer of human BNB endothelial cell proliferation in vitro, with heparin serving as an important co-factor. The VEGF effect on proliferation has a narrow dose response range between $10-50 \mathrm{ng} / \mathrm{mL}$. There is redundancy in human BNB endothelial cell proliferation in vitro, as hydrocortisone and bFGF were capable of inducing cellular proliferation although these mitogens were less efficient and required higher molar concentrations. However, they possessed broader "therapeutic windows" than VEGF [5-fold broader with hydrocortisone and 40-fold with bFGF]. TGF- $\beta 1$ inhibited human BNB endothelial cell proliferation in vitro with potency enhanced in the absence of heparin that was sustained at higher concentrations. GDNF mildly induced human BNB endothelial cell proliferation in vitro in the presence of heparin, but became an inhibitor of endothelial cell growth when heparin was absent.

\section{VEGF potently induces pHEndEC angiogenesis in vitro}

VEGF at a concentration of $0.1 \mathrm{ng} / \mathrm{mL}(2.6 \mathrm{pM})$ was the most effective inducer of pHEndEC angiogenesis in vitro, defined as the mean number of microvessels/field (Figure 4A) and mean total capillary length/field (Figure 4B) under the influence of Matrigel ${ }^{\mathrm{TM}}$. This concentration of VEGF induced a mean of 19.0 ( \pm 0.6) microvessels/field, compared to 6.3 \pm 1.2 microvessels/field with basal medium that lacked exogenous mitogens. Thus, VEGF induced a mean 3.0-fold increase in the number of microvessels on Matrigel ${ }^{\mathrm{TM}}$ Basement Membrane Matrix over basal conditions. VEGF was less potent at $10 \mathrm{ng} / \mathrm{mL}(12.3 \pm 1.8$ microvessels/field) and lost its effect on angiogenesis by $100 \mathrm{ng} / \mathrm{mL}$ bFGF was as effective as VEGF in inducing pHEndEC angiogenesis, with a mean of $19.0( \pm 4.5)$ microvessels/ 
field at a concentration of $10 \mathrm{ng} / \mathrm{mL}$ ( $581 \mathrm{pM}$ ), with a significant increase compared to 0.1 $\mathrm{ng} / \mathrm{mL}$. There was loss of efficacy in bFGF-induced angiogenesis at a concentration of 500 $\mathrm{ng} / \mathrm{mL}(10.3 \pm 1.5$ microvessels/ field). GDNF ( $1 \mathrm{ng} / \mathrm{mL}, 3.3 \mathrm{pM})$ and hydrocortisone (10 $\mathrm{nM}$ ) had small, but significant effects on pHEndEC angiogenesis (mean number of microvessels/field of $10.7 \pm 2.2$ and $11.0 \pm 2.5$ respectively) compared to basal conditions, while TGF- $\beta 1$ had no significant effect on the number of induced microvessels, as shown in Figure 4A.

Similarly, VEGF $0.1 \mathrm{ng} / \mathrm{mL}$ ( $2.6 \mathrm{pM})$ induced a maximum mean total capillary length of $5490 \pm 405 \mu \mathrm{m} /$ field, compared to $1400 \pm 655 \mu \mathrm{m} /$ field under basal conditions, representing a mean 3.9-fold increase in total capillary length. There was a gradual reduction in VEGFinduced angiogenesis based on this parameter at higher concentrations as previously described with the number of microvessels formed. As described above, bFGF $10 \mathrm{ng} / \mathrm{mL}$ $(581 \mathrm{pM})$ had a similar angiogenic effect to VEGF $(4780 \pm 1710 \mu \mathrm{m} / \mathrm{field})$, albeit at a 223fold higher molar concentration, as shown in Figure 4B. The bFGF dose-effect relationship on the mean total capillary length between $0.1-500 \mathrm{ng} / \mathrm{mL}$ is similar to that described previously. GDNF $(1 \mathrm{ng} / \mathrm{mL}, 3.3 \mathrm{pM})$ and hydrocortisone $(10 \mathrm{nM})$ had significant effects on the mean total induced pHEndEC capillary length $(2500 \pm 390 \mu \mathrm{m} / \mathrm{field}$ and $3060 \pm 758 \mu \mathrm{m} /$ field respectively) compared to basal conditions, while TGF- $\beta 1$ had no significant effect on mean total capillary length, as shown in Figure 4B. Matrigel ${ }^{\mathrm{TM}}$-supported angiogenesis did not occur at 4 hours with heparin absent in these series of experiments, with clusters of cells seen without significant microvessel formation.

These data suggest that VEGF, in picomolar concentrations, potently induced human BNB angiogenesis on a Matrigel ${ }^{\mathrm{TM}}$ Basement Membrane Matrix in vitro. This process was redundant, as bFGF, hydrocortisone and GDNF (in descending order of effect) were capable of inducing pHEndEC angiogenesis, although less efficiently than VEGF or at much higher molar concentrations. TGF- $\beta 1$ did not have a significant effect on human BNB angiogenesis in vitro relative to basal conditions without added mitogens.

\section{VEGF induces complete pHEndEC monolayer wound healing in vitro}

Consecutive time-lapse phase contrast photomicrographs demonstrated that pHEndEC monolayer wound healing following sterile micropipette injury in the presence of heparin occurred in three phases; 0-4 hours: no appreciable change in wound size, 4-18 hours: endothelial cell migration across the wound with reduction in wound width, and 18-30 hours: endothelial cell proliferation. Under basal conditions without exogenous mitogens, pHEndEC migration across the wound occurred at a mean rate of $42.9 \pm 3.0 \mu \mathrm{m} / \mathrm{hr} .10 \mathrm{ng} /$ mL VEGF $(0.26 \mathrm{nM})$ was most effective at inducing cellular migration across the wound 4 18 hours after injury, at a rate of $54.4 \pm 2.8 \mu \mathrm{m} / \mathrm{hr}$, representing a $26.8 \%$ mean increase in the rate of cellular migration during wound closure in vitro, as shown in Figure 5. There was a reduction in the rate of VEGF-mediated cellular migration observed with $100 \mathrm{ng} / \mathrm{mL}$ ( 2.62 $\mathrm{nM}$ ): $50.8 \pm 2.5 \mu \mathrm{m} / \mathrm{hr}$, compared to $10 \mathrm{ng} / \mathrm{mL}$ VEGF. $10 \mathrm{ng} / \mathrm{mL}$ bFGF (581 pM; $52.5 \pm 2.2$ $\mu \mathrm{m} / \mathrm{hr})$ and $100 \mathrm{nM}$ hydrocortisone $(49.9 \pm 3.6 \mu \mathrm{m} / \mathrm{hr})$ were the only other mitogens that significantly enhanced the mean rate pHEndEC migration across the wound during this healing phase in vitro (Figure 5). Higher concentrations of these mitogens were less effective or significantly inhibited cellular migration during wound healing relative to basal conditions, as seen with $1000 \mathrm{nM}$ hydrocortisone and $500 \mathrm{ng} / \mathrm{mL}$ bFGF. GDNF $(1 \mathrm{ng} / \mathrm{mL}$; $33 \mathrm{pM})$ had no appreciable effect on pHEndEC migration, while TGF- $\beta 1(0.1 \mathrm{ng} / \mathrm{mL} ; 4 \mathrm{pM})$ significantly inhibited cellular migration $(35.6 \pm 3.3 \mu \mathrm{m} / \mathrm{hr}$ ) compared to basal rates without exogenous mitogens, as shown in Figure 5.

In the absence of heparin or VEGF, the mean rate of cellular migration across the wound was $12.47 \pm 3.2 \mu \mathrm{m} / \mathrm{hr}$, representing a $71.9 \%$ mean reduction relative to basal migration 
under the influence of $25 \mathrm{U} / \mathrm{mL}$ heparin. VEGF $10 \mathrm{ng} / \mathrm{mL}$ and $100 \mathrm{mg} / \mathrm{mL}$ significantly increased cellular migration with heparin absent $(38.3 \pm 3.9 \mu \mathrm{m} / \mathrm{hr}$ and $29.1 \pm 3.2 \mu \mathrm{m} / \mathrm{hr}$ respectively); however, these rates remained significantly below endogenous pHEndEC migration across the wound 4-18 hours after injury under the influence of heparin. Interestingly, in the presence of heparin, only VEGF $10 \mathrm{ng} / \mathrm{mL}$ and $100 \mathrm{ng} / \mathrm{mL}$ were able to complete the pHEndEC wound healing process by 30 hours following sterile micropipette injury via increased cellular proliferation (Figure 6). No significant change in the mean residual wound widths following initial cellular migration was observed between 18-30 hours for the other mitogens tested (data not shown).These studies demonstrate an important role for exogenous heparin and VEGF, in picomolar to low nanomolar concentrations, in facilitating complete pHEndEC monolayer wound healing following sterile micropipette injury within 30 hours in vitro.

\section{DISCUSSION}

This study demonstrates an important role for VEGF in human BNB endothelial cell proliferation, angiogenesis and monolayer wound healing following direct trauma in vitro, implying that VEGF may be a key mediator of human endoneurial microvessel formation during development and recovery following traumatic injury. pHEndECs express VEGFR2, implying a direct effect of exogenous VEGF on these cells during proliferation, angiogenesis and recovery from direct trauma. Heparin is an important co-factor for the observed VEGF-mediated mitogenic effects, suggesting a direct role in facilitating functional interactions between VEGF-A 165 and VEGFR2, as suggested with human umbilical endothelial cells (Ashikari-Hada et al. 2005). PnMECs have been shown to express VEGF in vitro (Shimizu et al. 2011b), implying that basal pHEndEC cellular proliferation, angiogenesis and wound healing may be associated with endogenous VEGF production. However, exogenous VEGF in picomolar or low nanomolar concentrations (with a well-defined 'dose-response curve') robustly facilitated these biological processes with human BNB-forming microvascular endothelial cells in vitro, suggesting that other resident peripheral nerve endoneurial cells such as pericytes and Schwann cells may contribute to BNB microvessel development and recovery from injury. This is consistent with the concept that VEGF functions as a paracrine mediator based on observations between neoplastic cells and nearby endothelial cells during tumor growth and metastatic spread (Roskoski 2007).

In vivo, exogenous VEGF administered via gene transfer using a plasmid DNA encoding human VEGF-1 or VEGF-2 has been shown to induce vascular proliferation in the sciatic nerves of streptozosin-induced diabetic rats and alloxan-induced diabetic rabbits, associated with disease reversal (Schratzberger et al. 2001). A double-blinded clinical trial of intramuscular VEGF gene transfer in human diabetic polyneuropathy demonstrated improved sensory perception and less nociception, without significant change in nerve conduction potentials (Ropper et al. 2009). These observations support the notion that VEGF is a potent vascular mitogen in peripheral nerves, required for neovascularization and axonal regeneration following injury (Pola et al. 2004). Our study, however, demonstrated some redundancy in VEGF-mediated human BNB endothelial cell proliferation, angiogenesis and wound healing in vitro. Hydrocortisone and bFGF were capable of inducing pHEndEC proliferation and migration across a sterile wound in the presence of heparin, although less efficiently than VEGF, and bFGF was equally effective at inducing BNB angiogenesis in vitro on a Matrigel ${ }^{\mathrm{TM}}$ Basement Membrane Matrix, although at a higher molar concentration than VEGF. Interestingly, only VEGF was capable of complete wound healing within 30 hours following sterile monolayer injury via cellular proliferation. This implies a non-redundant role for VEGF during the final phase of human BNB endothelial cell wound recovery following direct trauma in vitro. 
We observed that TGF- $\beta 1$ inhibited pHEndEC proliferation in vitro as well as migration during the second phase of recovery from sterile micropipette injury, with no appreciable effect on angiogenesis. These observations are consistent with its role as a paracrine inhibitor of epithelial and endothelial cell growth in normal tissues (Wakefield and Roberts 2002). Signaling is known to occur via heterotetrameric complex of two transmembrane receptor serine/threonine kinases, consisting of a type II ligand binding receptor (TGF $\beta$ RII) and a type I signaling receptor (TGF $\beta$ RI) (Wakefield and Roberts 2002). pHEndECs express both receptors in vitro (Figure 1), implying a direct inhibitory effect of TGF- $\beta 1$ on these biological processes. The anti-proliferative effect of TGF- $\beta 1$ on pHEndECs was inhibited by heparin, as observed in rat models of liver fibrosis and acute lung injury (Lee et al. 2011; Mu et al. 2012). TGF- $\beta 1$ is known to bind heparin with high affinity (McCaffrey et al. 1992; Rider 2006), with a study suggesting a direct role for heparin in potentiating the biologic activity of TGF- $\beta 1$-mediated inhibition of rat and bovine aortic smooth muscle cell proliferation in vitro. However, this effect was not seen in human saphenous vein smooth muscle cells in vitro (McCaffrey et al. 1989), suggesting differential mechanistic effects of TGF- $\beta 1$-heparin interactions dependent on species and tissue origin.

GDNF demonstrated a small effect on pHEndEC proliferation and angiogenesis in vitro, with no significant effect on in vitro BNB monolayer wound healing following direct trauma in the presence of heparin. GDNF demonstrated inhibitory effects on pHEndEC proliferation with heparin absent. GDNF has been shown to bind heparin with high affinity (Rider 2006), suggesting a possible role in facilitating GDNF-GFRa 1-RET Tyrosine kinase signaling. The GDNF effect described above is in contrast to its potent ability to restore in vitro BNB restrictive barrier characteristics following non-traumatic diffuse endothelial injury mediated by serum withdrawal. GDNF, in picomolar concentrations, induced cytoskeletal modifications with F-actin filament relocation from within the cytoplasm towards cell membranes associated with more continuous intercellular contacts that provided the scaffold for adherens and tight junction formation within 48 hours, associated with increased transendothelial electrical resistance and reduced solute permeability to high molecular weight fluoresceinated dextran, back to pre-injury levels (Yosef and Ubogu 2012).

Sterile micropipette injury differs from endothelial cell injury mediated by serum withdrawal, as there is significant endothelial cell loss following direct trauma (Lee and Kay 2006), in contrast to endothelial cell detachment from neighboring cells with residual focal intercellular contacts secondary to cytoplasmic retraction observed following serum withdrawal in vitro (Yosef and Ubogu 2012). Following traumatic in vitro BNB injury, endothelial cell migration across the wound (4-18 hours) followed by proliferation (18-30 hours) was necessary for complete recovery. Under the influence of GDNF, surviving endothelial cells at the edge of the wound were observed to send cytoplasmic processes across the wound based on time-lapsed phase contrast micrographs, with minimal effect on reducing wound size compared to basal conditions. Taken with our recently published study, we hypothesize that GDNF may be essential for inducing cytoskeletal changes necessary for the formation of restrictive intercellular junctions following human BNB endothelial cell proliferation and contact inhibition in vitro.

\section{CONCLUSIONS}

This study demonstrates an important role for VEGF in human BNB endothelial cell proliferation, angiogenesis and traumatic wound healing in vitro, enhanced by heparin. The VEGF-mediated effects are dose-dependent, with a characteristic "inverted U" shaped curve with well-defined dose-effect "therapeutic windows" in the picomolar or low nanomolar range. This study suggests important physiological roles for VEGF in human BNB microvascular development and recovery following injury in vivo. pHEndECs express 
VEGFR2, implying a direct means by which exogenous VEGF can facilitate these biologic effects. Further work is required to determine the key signaling pathways and downstream regulators in human peripheral nerves as a means to further understand human peripheral nerve microvascular development and BNB formation during embryogenesis and early postnatal life, as well as the reparative processes that occur as a consequence of direct traumatic injury or peripheral neuropathies associated with pathologic microvascular alterations such as diabetes mellitus.

\section{Acknowledgments}

Special thanks to Dr. Monique Stins for providing THBMECs. Aspects of this study were presented in part in abstract form at the 2011 American Academy of Neurology meeting, Honolulu, Hawaii, USA and the 2011 Peripheral Nerve Society meeting, Potomac, Maryland, USA. This work was supported by a Baylor College of Medicine New Investigator Start-Up Award (2007-2011). The Neuromuscular Immunopathology Research Laboratory is currently supported by National Institutes of Health grants R21 NS073702, R21 NS078226 and R01 NS075212, and a subaward P30 AI27767 to E.E.U. The funding sources had no involvement in the conduct of the research, manuscript preparation, data collection/ analyses or decision to submit this work for publication. The content is solely the responsibility of the authors and does not necessarily represent the official views of the NIH.

\section{REFERENCES}

Abe M, Sano Y, Maeda T, Shimizu F, Kashiwamura Y, Haruki H, Saito K, Tasaki A, Kawai M, Terasaki T, Kanda T. Establishment and characterization of human peripheral nerve microvascular endothelial cell lines: a new in vitro blood-nerve barrier (BNB) model. Cell Struct Funct. 2012; 37(2):89-100. [PubMed: 22672995]

Aird W. Phenotypic heterogeneity of the endothelium: I. Structure, function, and mechanisms. Circ Res. 2007a; 100(2):158-173. [PubMed: 17272818]

Aird W. Phenotypic heterogeneity of the endothelium: II. Representative vascular beds. Circ Res. 2007b; 100(2):174-190. [PubMed: 17272819]

Al Ahmad A, Gassmann M, Ogunshola O. Maintaining blood-brain barrier integrity: pericytes perform better than astrocytes during prolonged oxygen deprivation. J Cell Physiol. 2009; 218(3):612-622. [PubMed: 19016245]

Allt G, Lawrenson J. The blood-nerve barrier: enzymes, transporters and receptors--a comparison with the blood-brain barrier. Brain Res Bull. 2000; 52(1):1-12. [PubMed: 10779695]

Arai K, Jin G, Navaratna D, Lo E. Brain angiogenesis in developmental and pathological processes: neurovascular injury and angiogenic recovery after stroke. FEBS J. 2009; 276(17):4644-4652. [PubMed: 19664070]

Ashikari-Hada S, Habuchi H, Kariya Y, Kimata K. Heparin regulates vascular endothelial growth factor165-dependent mitogenic activity, tube formation, and its receptor phosphorylation of human endothelial cells. Comparison of the effects of heparin and modified heparins. J Biol Chem. 2005; 280(36):31508-31515. [PubMed: 16027124]

Bell M, Weddell A. A descriptive study of the blood vessels of the sciatic nerve in the rat, man and other mammals. Brain. 1984a; 107(Pt 3):871-898. [PubMed: 6478181]

Bell M, Weddell A. A morphometric study of intrafascicular vessels of mammalian sciatic nerve. Muscle Nerve. 1984b; 7(7):524-534. [PubMed: 6544371]

Bendfeldt K, Radojevic V, Kapfhammer J, Nitsch C. Basic fibroblast growth factor modulates density of blood vessels and preserves tight junctions in organotypic cortical cultures of mice: a new in vitro model of the blood-brain barrier. J Neurosci. 2007; 27(12):3260-3267. [PubMed: 17376986]

Engelhardt B, Ransohoff R. The ins and outs of T-lymphocyte trafficking to the CNS: anatomical sites and molecular mechanisms. Trends Immunol. 2005; 26(9):485-495. [PubMed: 16039904]

Förster C, Silwedel C, Golenhofen N, Burek M, Kietz S, Mankertz J, Drenckhahn D. Occludin as direct target for glucocorticoid-induced improvement of blood-brain barrier properties in a murine in vitro system. J Physiol. 2005; 565(Pt 2):475-486. [PubMed: 15790664]

Galvan V, Greenberg D, Jin K. The role of vascular endothelial growth factor in neurogenesis in adult brain. Mini Rev Med Chem. 2006; 6(6):667-669. [PubMed: 16787377] 
Garcia C, Darland D, Massingham L, D'Amore P. Endothelial cell-astrocyte interactions and TGF beta are required for induction of blood-neural barrier properties. Brain Res Dev Brain Res. 2004; 152(1):25-38.

Guo S, Lo E. Dysfunctional cell-cell signaling in the neurovascular unit as a paradigm for central nervous system disease. Stroke. 2009; 40(3 Suppl):S4-S7. [PubMed: 19064781]

Hirakawa H, Okajima S, Nagaoka T, Takamatsu T, Oyamada M. Loss and recovery of the blood-nerve barrier in the rat sciatic nerve after crush injury are associated with expression of intercellular junctional proteins. Exp Cell Res. 2003; 284(2):196-210. [PubMed: 12651153]

Kanda T, Numata Y, Mizusawa H. Chronic inflammatory demyelinating polyneuropathy: decreased claudin-5 and relocated ZO-1. J Neurol Neurosurg Psychiatry. 2004; 75(5):765-769. [PubMed: 15090575]

Kashiwamura Y, Sano Y, Abe M, Shimizu F, Haruki H, Maeda T, Kawai M, Kanda T. Hydrocortisone enhances the function of the blood-nerve barrier through the up-regulation of claudin-5. Neurochem Res. 2011; 36(5):849-855. [PubMed: 21293925]

Krizanac-Bengez L, Mayberg M, Janigro D. The cerebral vasculature as a therapeutic target for neurological disorders and the role of shear stress in vascular homeostatis and pathophysiology. Neurol Res. 2004; 26(8):846-853. [PubMed: 15727268]

Latker C, Shinowara N, Miller J, Rapoport S. Differential localization of alkaline phosphatase in barrier tissues of the frog and rat nervous systems: a cytochemical and biochemical study. J Comp Neurol. 1987; 264(3):291-302. [PubMed: 3500190]

Lee J, Kay E. FGF-2-induced wound healing in corneal endothelial cells requires Cdc42 activation and Rho inactivation through the phosphatidylinositol 3-kinase pathway. Invest Ophthalmol Vis Sci. 2006; 47(4):1376-1386. [PubMed: 16565371]

Lee JH, Lee H, Joung YK, Jung KH, Choi JH, Lee DH, Park KD, Hong SS. The use of low molecular weight heparin-pluronic nanogels to impede liver fibrosis by inhibition the TGF-beta/Smad signaling pathway. Biomaterials. 2011; 32(5):1438-1445. [PubMed: 21074845]

Malmgren L, Olsson Y. Differences between the peripheral and the central nervous system in permeability to sodium fluorescein. J Comp Neurol. 1980; 191(1):103-107. [PubMed: 7400388]

Man S, Ubogu E, Ransohoff R. Inflammatory cell migration into the central nervous system: a few new twists on an old tale. Brain Pathol. 2007; 17(2):243-250. [PubMed: 17388955]

Man S, Ubogu E, Williams K, Tucky B, Callahan M, Ransohoff R. Human brain microvascular endothelial cells and umbilical vein endothelial cells differentially facilitate leukocyte recruitment and utilize chemokines for T cell migration. Clin Dev Immunol. 2008; 2008:384982. [PubMed: 18320011]

Marchi N, Teng Q, Ghosh C, Fan Q, Nguyen M, Desai N, Bawa H, Rasmussen P, Masaryk T, Janigro D. Blood-brain barrier damage, but not parenchymal white blood cells, is a hallmark of seizure activity. Brain Res. 2010; 1353:176-186. [PubMed: 20599815]

McCaffrey TA, Falcone DJ, Brayton CF, Agarwal LA, Welt FG, Weksler BB. Transforming growth factor-beta activity is potentiated by heparin via dissociation of the transforming growth factorbeta/alpha 2-macroglobulin inactive complex. J Cell Biol. 1989; 109(1):441-448. [PubMed: 2473082]

McCaffrey TA, Falcone DJ, Du B. Transforming growth factor-beta 1 is a heparin-binding protein: identification of putative heparin-binding regions and isolation of heparins with varying affinity for TGF-beta 1. J Cell Physiol. 1992; 152(2):430-440. [PubMed: 1639873]

Mu E, Ding R, An X, Li X, Chen S, Ma X. Heparin attenuates lipopolysaccharide-induced acute lung injury by inhibiting nitric oxide synthase and TGF-beta/Smad signaling pathway. Thromb Res. 2012; 129(4):479-485. [PubMed: 22035631]

Murphy H, Bakopoulos N, Dame M, Varani J, Ward P. Heterogeneity of vascular endothelial cells: differences in susceptibility to neutrophil-mediated injury. Microvasc Res. 1998; 56(3):203-211. [PubMed: 9828158]

Olsson Y. Studies on vascular permeability in peripheral nerves. IV. Distribution of intravenously injected protein tracers in the peripheral nervous system of various species. Acta Neuropathol. 1971; 17(2):114-126. [PubMed: 5101595] 
Olsson Y. Microenvironment of the peripheral nervous system under normal and pathological conditions. Crit Rev Neurobiol. 1990; 5(3):265-311. [PubMed: 2168810]

Orte C, Lawrenson J, Finn T, Reid A, Allt G. A comparison of blood-brain barrier and blood-nerve barrier endothelial cell markers. Anat Embryol (Berl). 1999; 199(6):509-517. [PubMed: 10350131]

Poduslo J, Curran G, Berg C. Macromolecular permeability across the blood-nerve and blood-brain barriers. Proc Natl Acad Sci U S A. 1994; 91(12):5705-5709. [PubMed: 8202551]

Poduslo J, Curran G, Dyck P. Increase in albumin, IgG, and IgM blood-nerve barrier indices in human diabetic neuropathy. Proc Natl Acad Sci U S A. 1988; 85(13):4879-4883. [PubMed: 3387444]

Pola R, Aprahamian TR, Bosch-Marce M, Curry C, Gaetani E, Flex A, Smith RC, Isner JM, Losordo DW. Age-dependent VEGF expression and intraneural neovascularization during regeneration of peripheral nerves. Neurobiol Aging. 2004; 25(10):1361-1368. [PubMed: 15465634]

Pummi K, Heape A, Grénman R, Peltonen J, Peltonen S. Tight junction proteins ZO-1, occludin, and claudins in developing and adult human perineurium. J Histochem Cytochem. 2004; 52(8):10371046. [PubMed: 15258179]

Reina M, López A, Villanueva M, de Andrés J, León G. [Morphology of peripheral nerves, their sheaths, and their vascularization]. Rev Esp Anestesiol Reanim. 2000; 47(10):464-475. [PubMed: 11171467]

Reina M, López A, Villanueva M, De Andrés J, Machés F. [The blood-nerve barrier in peripheral nerves]. Rev Esp Anestesiol Reanim. 2003; 50(2):80-86. [PubMed: 12712870]

Rider CC. Heparin/heparan sulphate binding in the TGF-beta cytokine superfamily. Biochem Soc Trans. 2006; 34(Pt 3):458-460. [PubMed: 16709187]

Ropper AH, Gorson KC, Gooch CL, Weinberg DH, Pieczek A, Ware JH, Kershen J, Rogers A, Simovic D, Schratzberger P, Kirchmair R, Losordo D. Vascular endothelial growth factor gene transfer for diabetic polyneuropathy: a randomized, double-blinded trial. Ann Neurol. 2009; 65(4): 386-393. [PubMed: 19399887]

Roskoski R Jr. Vascular endothelial growth factor (VEGF) signaling in tumor progression. Crit Rev Oncol Hematol. 2007; 62(3):179-213. [PubMed: 17324579]

Sadowska G, Malaeb S, Stonestreet B. Maternal glucocorticoid exposure alters tight junction protein expression in the brain of fetal sheep. Am J Physiol Heart Circ Physiol. 2010; 298(1):H179-H188. [PubMed: 19855054]

Sano Y, Shimizu F, Nakayama H, Abe M, Maeda T, Ohtsuki S, Terasaki T, Obinata M, Ueda M, Takahashi R, Kanda T. Endothelial cells constituting blood-nerve barrier have highly specialized characteristics as barrier-forming cells. Cell Struct Funct. 2007; 32(2):139-147. [PubMed: 18057801]

Schlessinger J. Common and distinct elements in cellular signaling via EGF and FGF receptors. Science. 2004; 306(5701):1506-1507. [PubMed: 15567848]

Schratzberger P, Walter DH, Rittig K, Bahlmann FH, Pola R, Curry C, Silver M, Krainin JG, Weinberg DH, Ropper AH, Isner JM. Reversal of experimental diabetic neuropathy by VEGF gene transfer. J Clin Invest. 2001; 107(9):1083-1092. [PubMed: 11342572]

Shabb J. Physiological substrates of cAMP-dependent protein kinase. Chem Rev. 2001; 101(8):23812411. [PubMed: 11749379]

Shibuya M. Vascular endothelial growth factor-dependent and -independent regulation of angiogenesis. BMB Rep. 2008; 41(4):278-286. [PubMed: 18452647]

Shibuya M. Brain angiogenesis in developmental and pathological processes: therapeutic aspects of vascular endothelial growth factor. FEBS J. 2009; 276(17):4636-4643. [PubMed: 19664071]

Shimizu F, Sano Y, Abe MA, Maeda T, Ohtsuki S, Terasaki T, Kanda T. Peripheral nerve pericytes modify the blood-nerve barrier function and tight junctional molecules through the secretion of various soluble factors. J Cell Physiol. 2011a; 226(1):255-266. [PubMed: 20665675]

Shimizu F, Sano Y, Haruki H, Kanda T. Advanced glycation end-products induce basement membrane hypertrophy in endoneurial microvessels and disrupt the blood-nerve barrier by stimulating the release of TGF-beta and vascular endothelial growth factor (VEGF) by pericytes. Diabetologia. 2011b; 54(6):1517-1526. [PubMed: 21409414] 
Shimizu F, Sano Y, Saito K, Abe MA, Maeda T, Haruki H, Kanda T. Pericyte-derived glial cell linederived neurotrophic factor increase the expression of claudin-5 in the blood-brain barrier and the blood-nerve barrier. Neurochem Res. 2012; 37(2):401-409. [PubMed: 22002662]

Smith C, Atchabahian A, Mackinnon S, Hunter D. Development of the blood-nerve barrier in neonatal rats. Microsurgery. 2001; 21(7):290-297. [PubMed: 11754428]

Sobue K, Yamamoto N, Yoneda K, Hodgson M, Yamashiro K, Tsuruoka N, Tsuda T, Katsuya H, Miura Y, Asai K, Kato T. Induction of blood-brain barrier properties in immortalized bovine brain endothelial cells by astrocytic factors. Neurosci Res. 1999; 35(2):155-164. [PubMed: 10616919]

Stonestreet B, Sadowska G, McKnight A, Patlak C, Petersson K. Exogenous and endogenous corticosteroids modulate blood-brain barrier development in the ovine fetus. Am J Physiol Regul Integr Comp Physiol. 2000; 279(2):R468-R477. [PubMed: 10938234]

Sun Y, Jin K, Xie L, Childs J, Mao X, Logvinova A, Greenberg D. VEGF-induced neuroprotection, neurogenesis, and angiogenesis after focal cerebral ischemia. J Clin Invest. 2003; 111(12):18431851. [PubMed: 12813020]

Takahashi M. The GDNF/RET signaling pathway and human diseases. Cytokine Growth Factor Rev. 2001; 12(4):361-373. [PubMed: 11544105]

Tang J, Wang J, Kong X, Yang J, Guo L, Zheng F, Zhang L, Huang Y, Wan Y. Vascular endothelial growth factor promotes cardiac stem cell migration via the PI3K/Akt pathway. Exp Cell Res. 2009; 315(20):3521-3531. [PubMed: 19800880]

Utsumi H, Chiba H, Kamimura Y, Osanai M, Igarashi Y, Tobioka H, Mori M, Sawada N. Expression of GFRalpha-1, receptor for GDNF, in rat brain capillary during postnatal development of the BBB. Am J Physiol Cell Physiol. 2000; 279(2):C361-C368. [PubMed: 10913002]

Wakefield L, Roberts A. TGF-beta signaling: positive and negative effects on tumorigenesis. Curr Opin Genet Dev. 2002; 12(1):22-29. [PubMed: 11790550]

Wang Y, Jin K, Mao X, Xie L, Banwait S, Marti H, Greenberg D. VEGF-overexpressing transgenic mice show enhanced post-ischemic neurogenesis and neuromigration. J Neurosci Res. 2007; 85(4):740-747. [PubMed: 17243175]

Weidenfeller C, Schrot S, Zozulya A, Galla H. Murine brain capillary endothelial cells exhibit improved barrier properties under the influence of hydrocortisone. Brain Res. 2005; 1053(1-2): 162-174. [PubMed: 16040011]

Yano K, Gale D, Massberg S, Cheruvu P, Monahan-Earley R, Morgan E, Haig D, von Andrian U, Dvorak A, Aird W. Phenotypic heterogeneity is an evolutionarily conserved feature of the endothelium. Blood. 2007; 109(2):613-615. [PubMed: 16990601]

Yosef N, Ubogu EE. GDNF restores human blood-nerve barrier function via RET tyrosine kinasemediated cytoskeletal reorganization. Microvasc Res. 2012; 83(3):298-310. [PubMed: 22326552]

Yosef N, Ubogu EE. An immortalized human blood-nerve barrier endothelial cell line for in vitro permeability studies. Cell Mol Neurobiol. 2013; 33(2):175-186. [PubMed: 23104242]

Yosef N, Xia R, Ubogu E. Development and characterization of a novel human in vitro blood-nerve barrier model using primary endoneurial endothelial cells. J Neuropathol Exp Neurol. 2010; 69(1): 82-97. [PubMed: 20010300]

Zheng Z, Yenari M. Post-ischemic inflammation: molecular mechanisms and therapeutic implications. Neurol Res. 2004; 26(8):884-892. [PubMed: 15727272] 


\section{$\leftarrow \mathrm{pBNB} \longrightarrow \quad \leftarrow$ iBNB $\longrightarrow \quad$ iBBB}
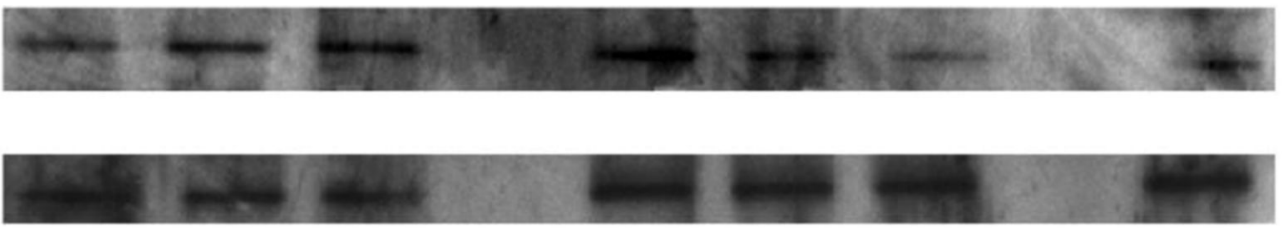

GR

$75 \mathrm{KDa}$

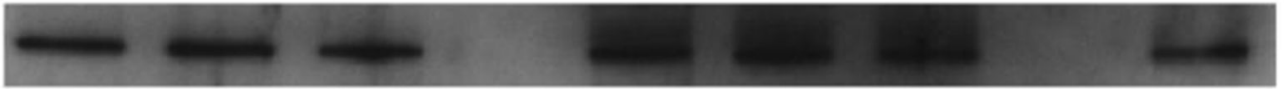

TGF $\beta$ RI

$53 \mathrm{KDa}$

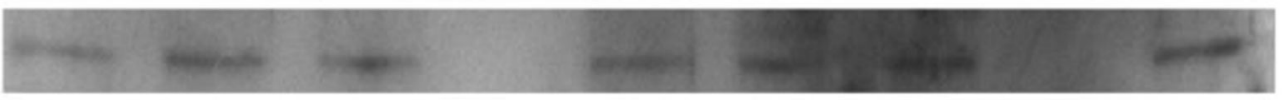

TGF $\beta R I I$

$50 \mathrm{KDa}$

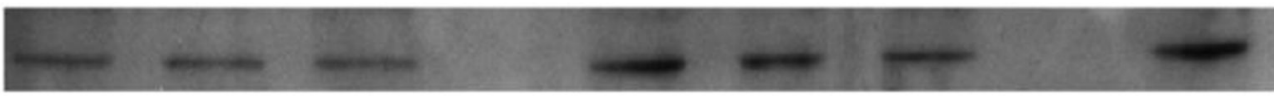

GFRa1

$65 \mathrm{KDa}$

$40 \mathrm{KDa}$
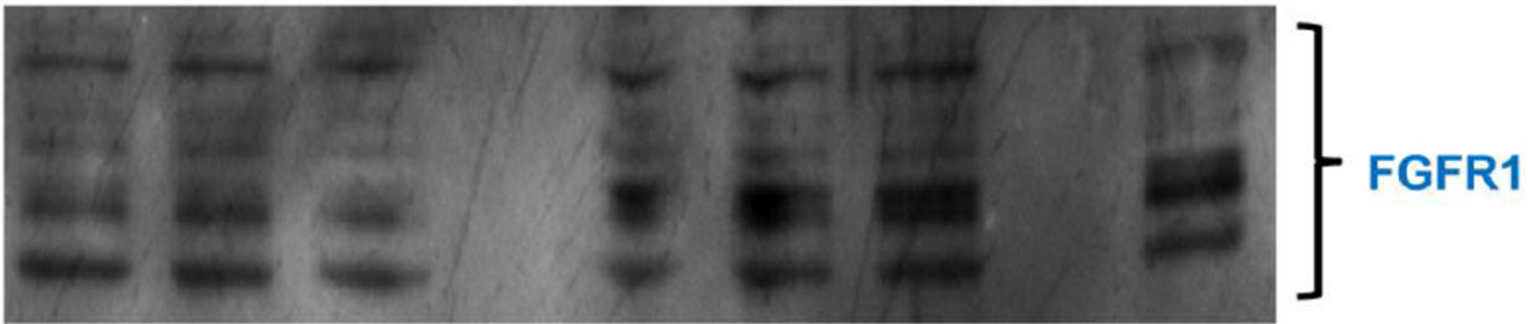

$37 \mathrm{KDa}$

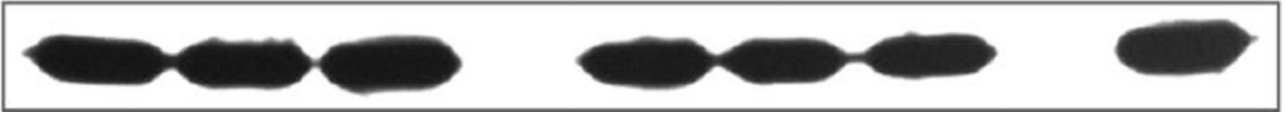

GAPDH

Figure 1. pHEndEC growth factor receptor expression

Representative composite digital autoradiographs following Western blot to detect specific growth factor receptors expressed by proliferating near-confluent pHEndECs (p-BNB), THEndECs (i-BNB) and THBMECs (i-BBB) are shown, with GAPDH serving as an internal protein loading control. Protein extracts from three isolates are displayed on the same autoradiograph to demonstrate similarity in growth factor receptor expression by these cell lines. Molecular weights of the detected proteins are shown on the left. 


\section{$\%$ change in proliferation relative to basal}

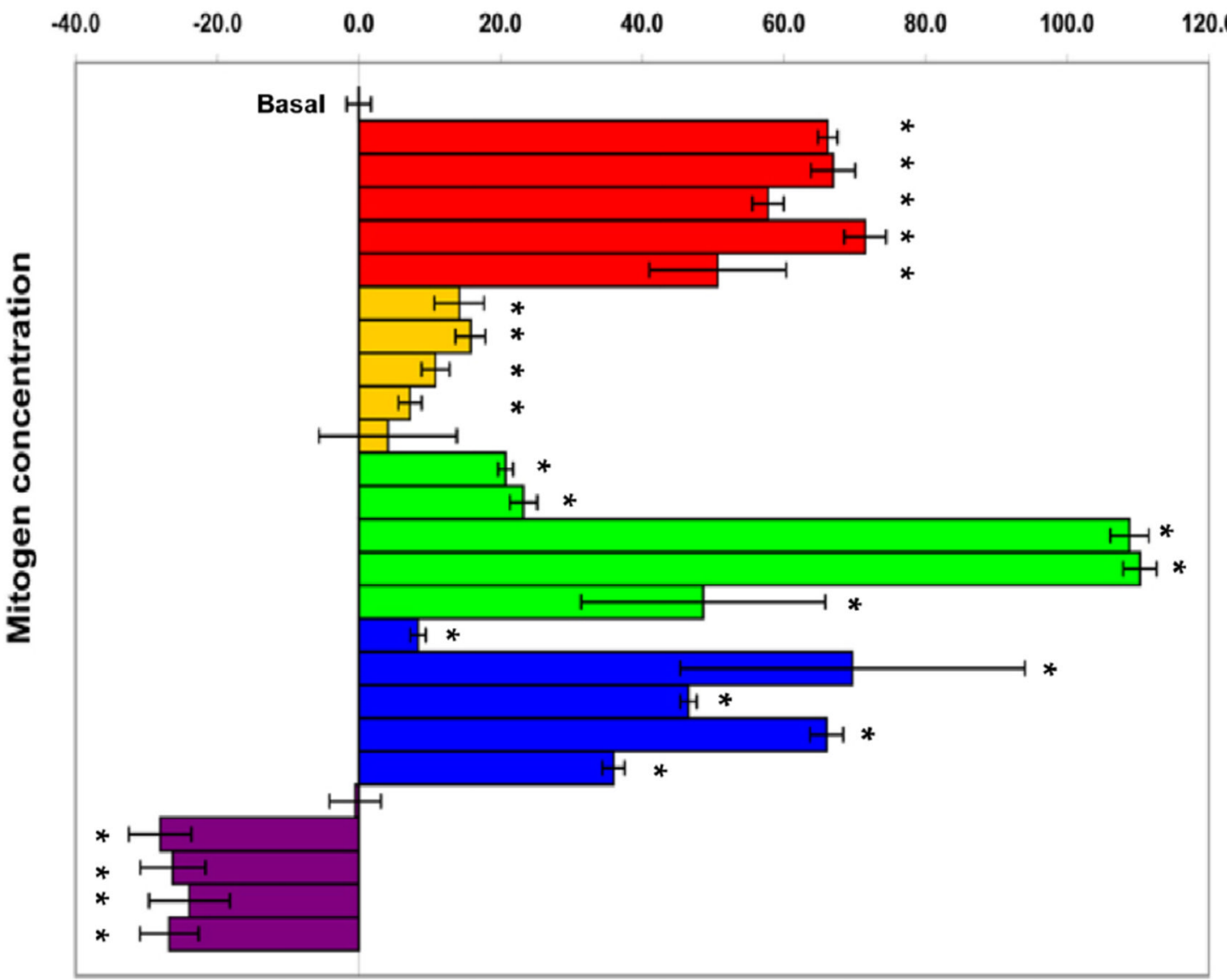

$\square 100 \mathrm{nM} \mathrm{HC}$ $\square 500 \mathrm{nM} \mathrm{HC}$ $\square 1000 \mathrm{nM} \mathrm{HC}$ $\square 2500 \mathrm{nM} \mathrm{HC}$ $\square 5000 \mathrm{nM} \mathrm{HC}$ 口GDNF $0.1 \mathrm{ng} / \mathrm{mL}$ 口GDNF $1 \mathrm{ng} / \mathrm{mL}$ 口GDNF $10 \mathrm{ng} / \mathrm{mL}$ 口GDNF $50 \mathrm{ng} / \mathrm{mL}$ 口GDNF $100 \mathrm{ng} / \mathrm{mL}$ 口VEGF $0.1 \mathrm{ng} / \mathrm{mL}$ 口VEGF $1 \mathrm{ng} / \mathrm{mL}$ 口VEGF $10 \mathrm{ng} / \mathrm{mL}$ 口VEGF $50 \mathrm{ng} / \mathrm{mL}$ 口VEGF $100 \mathrm{ng} / \mathrm{mL}$ - bFGF $0.1 \mathrm{ng} / \mathrm{mL}$ - bFGF $1 \mathrm{ng} / \mathrm{mL}$ - bFGF $10 \mathrm{ng} / \mathrm{mL}$ bFGF $100 \mathrm{ng} / \mathrm{mL}$ a bFF $500 \mathrm{ng} / \mathrm{mL}$ 口TGF $\beta 10.1 \mathrm{ng} / \mathrm{mL}$ -TGFß1 $1 \mathrm{ng} / \mathrm{mL}$ TGF $\beta 110 \mathrm{ng} / \mathrm{mL}$

TGFß1 $100 \mathrm{ng} / \mathrm{mL}$ 口TGF $\beta 1500 \mathrm{ng} / \mathrm{mL}$

Figure 2. In vitro $\mathrm{pHEndEC} \mathrm{proliferation} \mathrm{assay}$

The bar histographs depict pHEndEC proliferation as a percentage change relative to basal proliferation in the presence of $25 \mathrm{U} / \mathrm{mL}$ heparin for different concentrations of mitogens, as shown sequentially on the legend on the right. VEGF $(50 \mathrm{ng} / \mathrm{mL})$ is the most potent inducer of pHEndEC proliferation based on this assay. Mitogen proliferation efficacy is as follows: VEGF $>$ hydrocortisone $\simeq \mathrm{bFGF}>\mathrm{GDNF}$, with TGF- $\beta 1$ demonstrating significant inhibitory effects on pHEndEC proliferation at $1 \mathrm{ng} / \mathrm{mL}$ that remains relatively constant up to $500 \mathrm{ng} /$ $\mathrm{mL}$. * indicates $\mathrm{p}<0.05$ relative to basal proliferation. Error bars represent standard errors of the means, $\mathrm{N}=3$. 

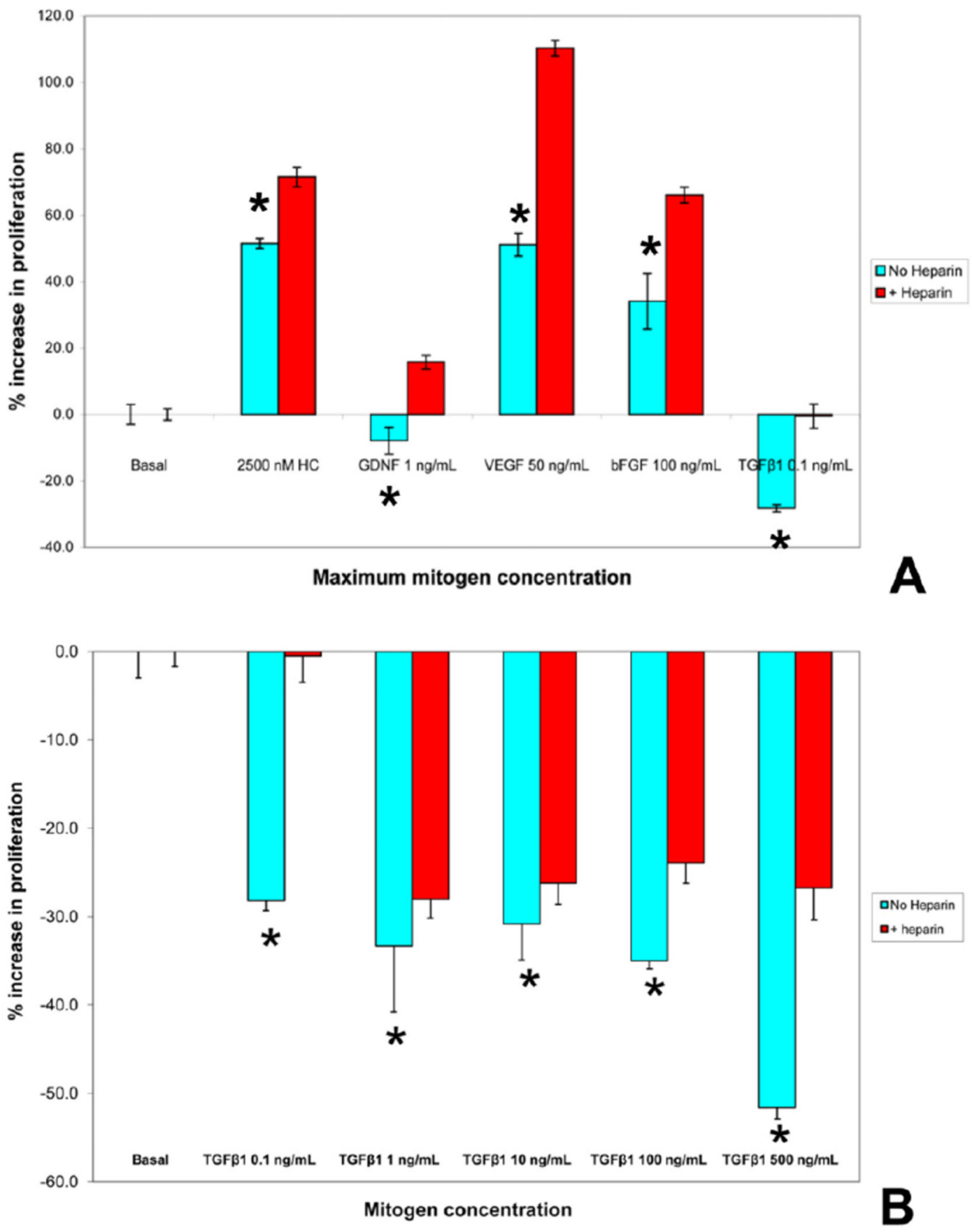

Figure 3. Effect of heparin on mitogen-induced pHEndEC proliferation

The bar histographs depict $\mathrm{pHEndEC} \mathrm{proliferation}$ as a percentage change of basal proliferation comparing maximum effective proliferative mitogen concentrations under with influence of heparin $(25 \mathrm{U} / \mathrm{mL})$, with growth without added heparin. Statistically significant reductions in pHEndEC proliferation are observed for all mitogens tested in the absence of heparin, with GDNF $1 \mathrm{ng} / \mathrm{mL}$ demonstrating a reversal in effect at $1 \mathrm{ng} / \mathrm{mL}$ and TGF- $\beta 1$ demonstrating potent inhibitory effects at $0.1 \mathrm{ng} / \mathrm{mL}$ (A). Further analyses of the TGF- $\beta 1$ mediated effects on pHEndEC proliferation demonstrates significantly increased inhibition in the absence of heparin that is relatively stable between $1-100 \mathrm{ng} / \mathrm{mL}$, with a more 
significant increase observed at $500 \mathrm{ng} / \mathrm{mL}(\mathbf{B}) . *$ indicates $\mathrm{p}<0.05$ relative to basal proliferation. Error bars represent standard errors of the means, $\mathrm{N}=3$. 


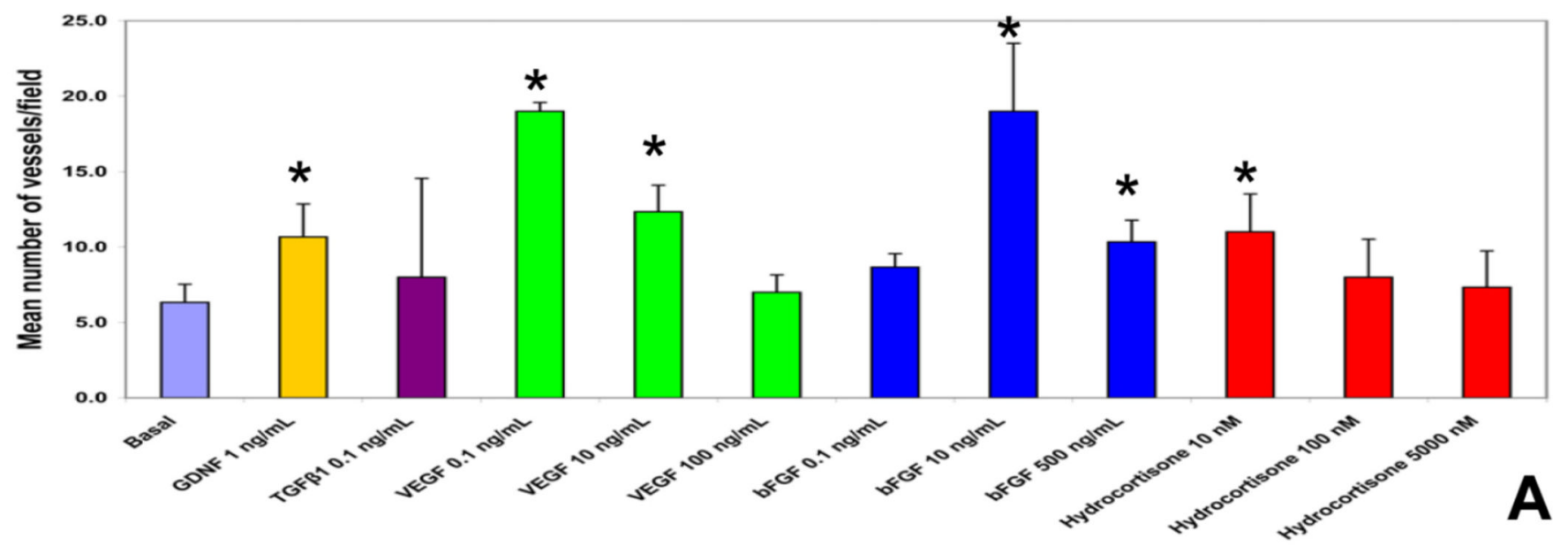

Mitogen

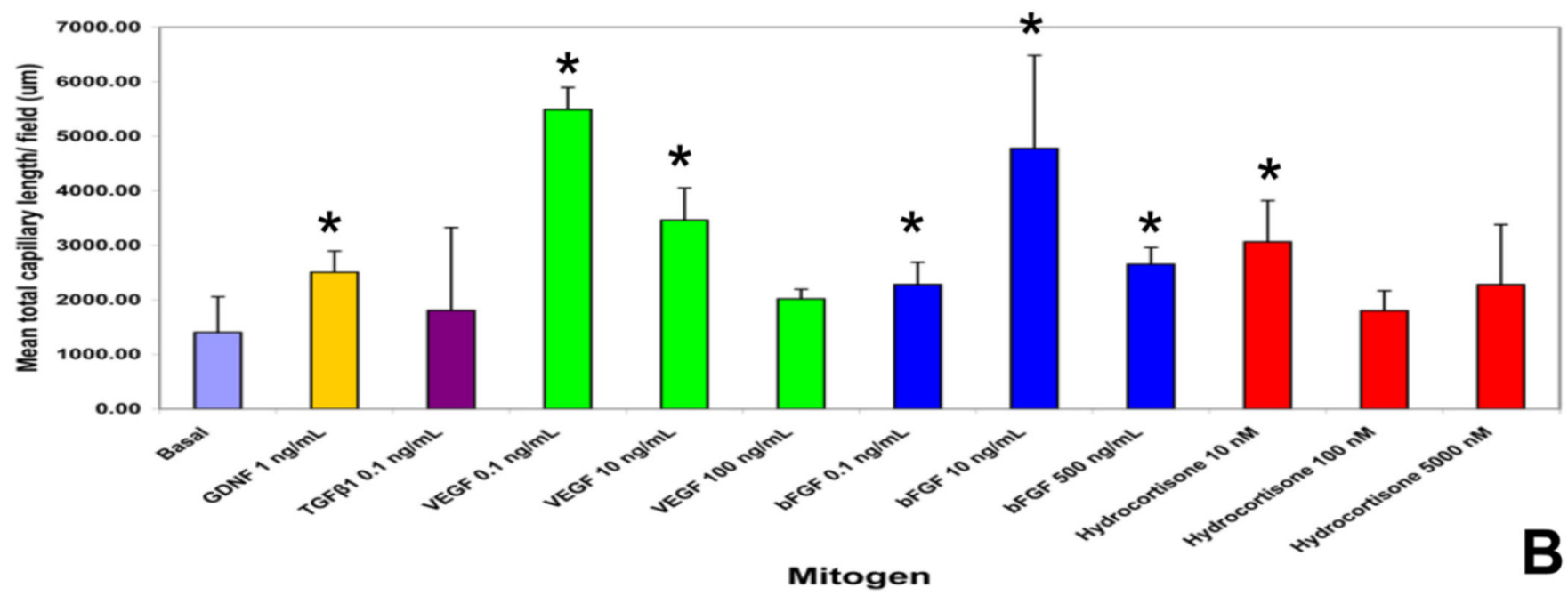

Figure 4. In vitro pHEndEC microvessel angiogenesis assay

The effect of different concentrations of mitogens on the mean number of microvessels (A) and mean total capillary length $(\mathbf{B})$ per field, as measures of mitogen-induced BNB endothelial cell angiogenesis is shown with bar histographs and compared to basal angiogenesis in vitro 4 hours after seeding freshly passaged cells on a Matrigel ${ }^{\text {TM }}$ Basement Membrane Matrix. VEGF $(0.1 \mathrm{ng} / \mathrm{mL})$ and bFGF $(10 \mathrm{ng} / \mathrm{mL})$ are most efficacious in inducing microvessel angiogenesis, with VEGF being more potent based on lower effective molar concentration. GDNF (1 ng/mL) and hydrocortisone $(10 \mathrm{nM})$ demonstrate smaller inductive effects on angiogenesis than VEGF and bFGF. These effects were statistically significant compared to angiogenesis without added mitogens. The observed VEGF, bFGF and hydrocortisone effects on angiogenesis are dose-dependent. TGF- $\beta 1$ does not demonstrate significant effects on pHEndEC angiogenesis at 4 hours in this assay. * indicates $\mathrm{p}<0.05$ relative to basal angiogenesis. Error bars represent standard errors of the means, $\mathrm{N}=3$. 


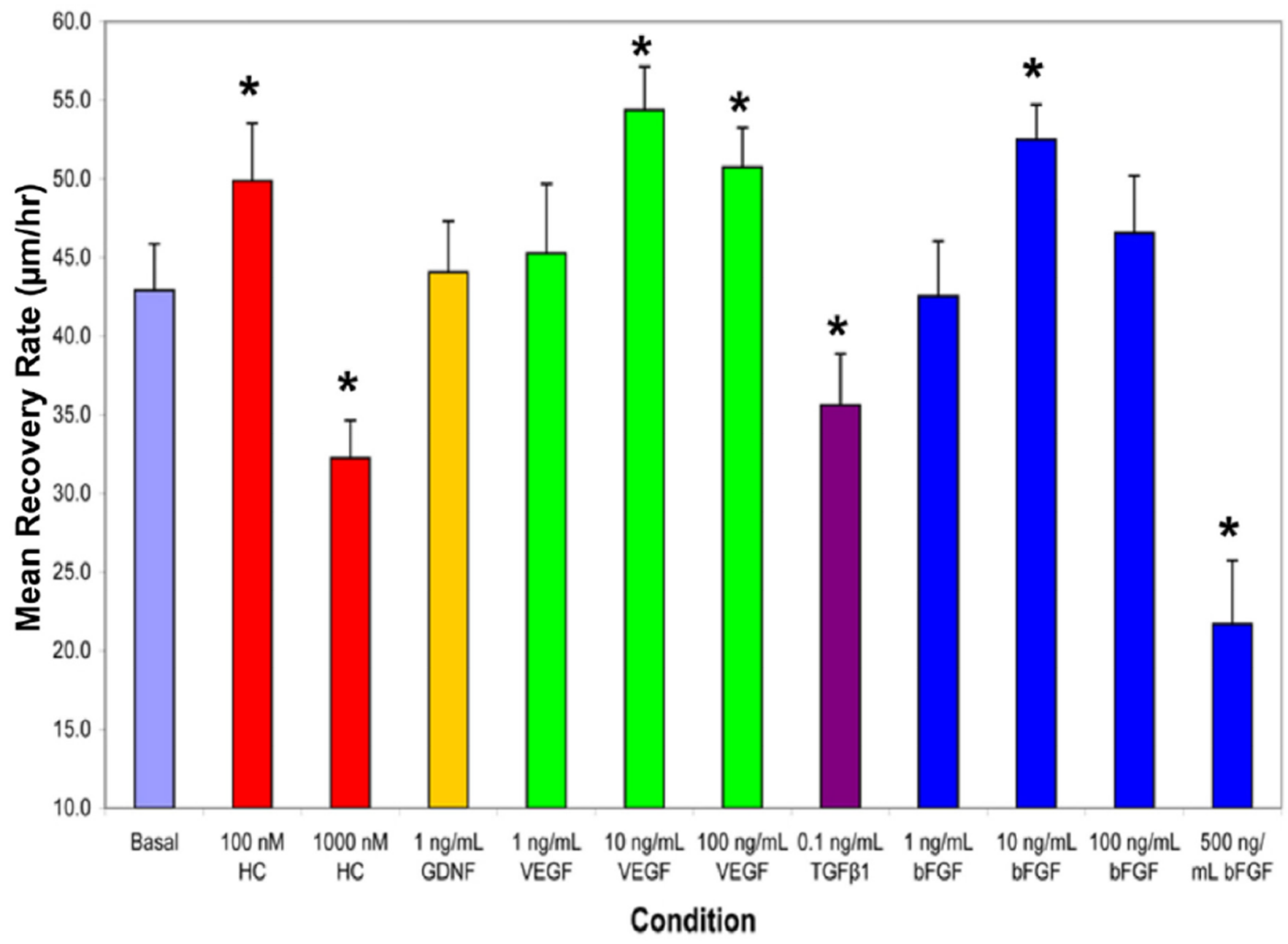

Figure 5. In vitro $\mathrm{pHEndEC}$ wound healing assay

The bar histographs demonstrate the mean recovery rate (in $\mu \mathrm{m} / \mathrm{hr}$ ) of confluent cultured pHEndEC monolayers between 4-18 hours following sterile micropipette injury, comparing different concentrations of mitogens to basal recovery rates without added mitogens in the presence of $25 \mathrm{U} / \mathrm{mL}$ heparin. This process is mediated by cellular migration across the wound. VEGF induces the most rapid recovery rate, maximal at $10 \mathrm{ng} / \mathrm{mL}$ that persisted (albeit less effective) at $100 \mathrm{ng} / \mathrm{mL}$. Less significant effects are seen with bFGF $(10 \mathrm{ng} / \mathrm{mL}$ ) and hydrocortisone $(100 \mathrm{nM})$, the only other mitogens that induced more rapid mean recovery rates compared to basal conditions. GDNF $(1 \mathrm{ng} / \mathrm{mL})$ demonstrates no appreciable effect on wound healing, while TGF- $\beta 1(0.1 \mathrm{ng} / \mathrm{mL})$ demonstrates an inhibitory effect on pHEndEC wound healing in these series of experiments. Hourly recovery rates from 10 nonoverlapping regions per tested condition were averaged in these series of experiments. * indicates p-value $<0.05$ relative to basal recovery. Error bars indicate standard errors of the mean. 


\section{Basal}
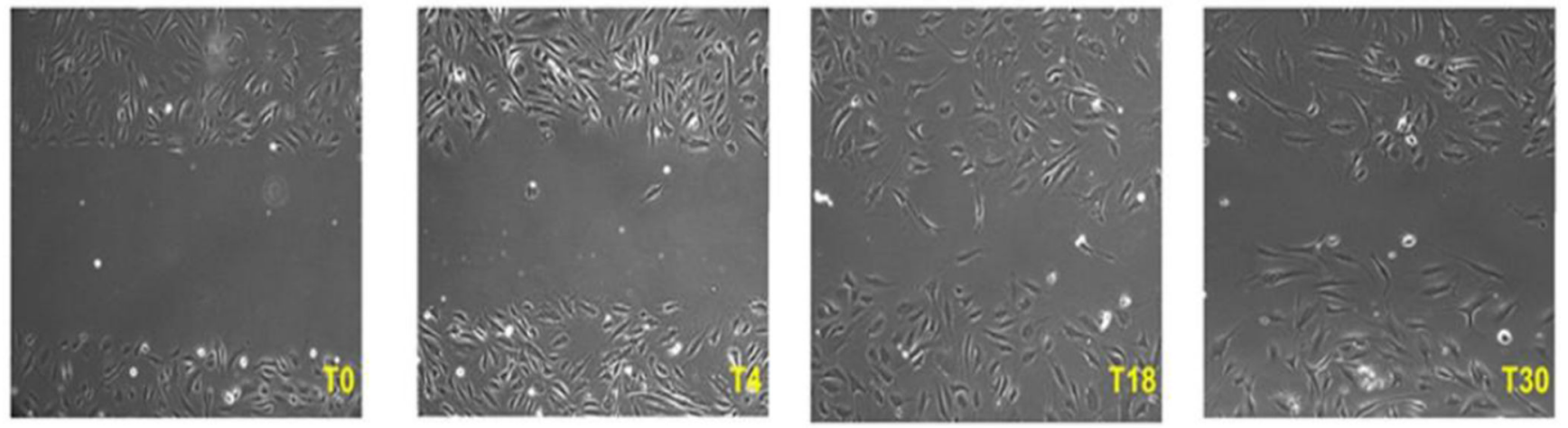

\section{VEGF $10 \mathrm{ng} / \mathrm{mL}$}
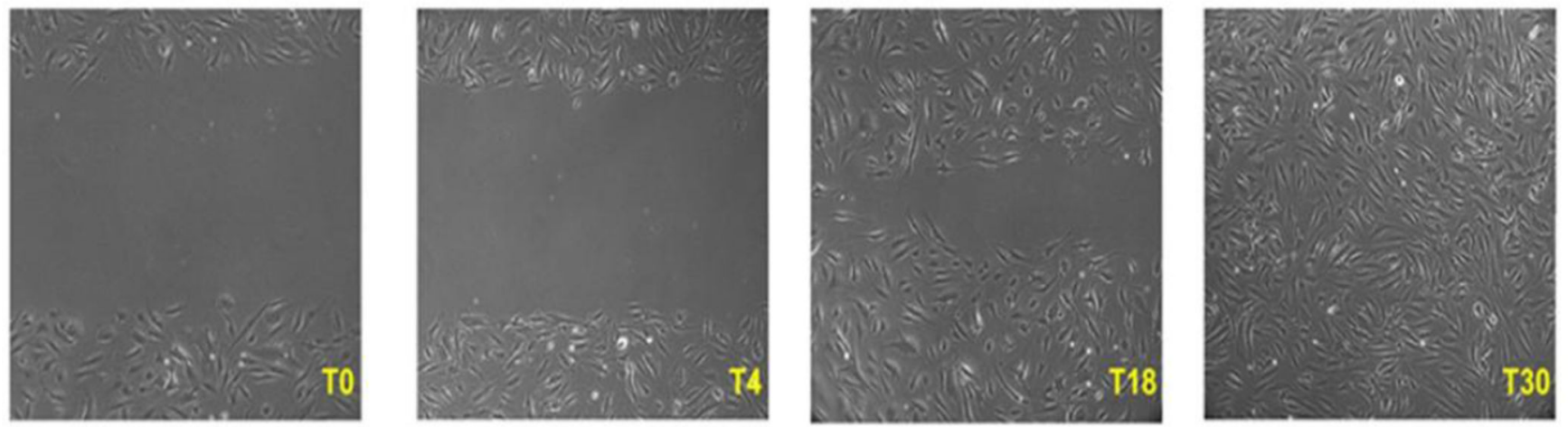

Figure 6. Effect of VEGF on complete pHEndEC monolayer recovery following sterile micropipette injury

Representative composite time-lapse digital photomicrographs of confluent cultured pHEndEC monolayers following sterile micropipette injury under basal conditions and following treatment with $10 \mathrm{ng} / \mathrm{mL}$ VEGF are shown at different time points. No significant change in mean wound width is observed between 0 and 4 hours following injury, with significant cellular migration across the wound occurring between 4 and 18 hours. VEGF $(10 \mathrm{ng} / \mathrm{mL})$ induced complete wound closure by 30 hours mediated by increased cellular proliferation. This was absent under basal conditions. T0: immediately after injury, T4: 4 hours after injury, T18: 18 hours after injury, T30: 30 hours after injury. 